\title{
EFFECT OF GOODWILL ON THE PERFORMANCE OF THE ORGANIZATION OF THE CONSTRUCTION SECTOR
}

\author{
Vladimir Okrepilov* \\ State Regional Centre for Standardization, Metrology and Testing in St. Petersburg, Russia \\ Marina Gravit \\ Saint Petersburg State Polytechnical University, Saint Petersburg, Russia \\ Ekaterina Nedviga \\ State Regional Centre for Standardization, Metrology and Testing, Saint Petersburg, Russia \\ Dudnik Oleg \\ Magadan Institute of Economics, Saint Petersburg, Russia
}

There are issues of Goodwill and reputation risk. Particular attention is paid to the development of national standards for the evaluation of the experience and reputation of organizations. It is described the justification of creating the standard for evaluation of the experience and reputation of the building organizations. There is the method of valuation of goodwill, intangible assets that evaluates construction company. The methodology includes five factors, each of which includes some subfactors. The assessment according to this method of Russian standard 56002-2014 "Evaluation of experience and reputation building organizations" the construction company will be assigned a code of business reputation.

Key words: Business reputation, Assessment methodology, Construction

\section{INTRODUCTION}

Nowadays, standardization not only develops and is an independent tool for ensuring quality and safety. There is a new vision of objects of standardization: one of them as products and services, as well as other intangible stakeholders - namely goodwill enterprise.

In April 2013, in the Russian Federation published the Federal Law № 44-FZ (ed. by 07.13.2015) "On the contract system in the area of procurement of goods, works and services for state and municipal needs", according to which (par. 2, Art. 31) "The Government of the Russian Federation the right to establish parties to procurement of certain goods, services ... additional requirements, including the presence of goodwill" [1]. In Russian Federation also discussed the draft federal law "On the construction contracts for state and municipal needs, as well as the needs of the individual legal entities", a feature of which is that it pointed to the need to ensure access to works construction contracts only to qualified contractors to meet their obligations and to provide the necessary indicators of quality, reliability and security. A key mechanism for the selection of qualified contractors is the procedure of qualification assessment, carried out by the self-regulatory organizations. Federal law "On self-regulatory organizations" given the right to self-regulatory organizations to develop standards themselves in order to eliminate factors that create unfair competition [02].

It is necessary to define the concept of "goodwill", standardize, identify it correctly according to the developed criteria to evaluate proxy authentication and therefore be able to reduce the reputational risks for the enterprise. The difficulty lies in the fact that goodwill organization - complex characteristic, multi-faceted and complex to identify and evaluate. Directly or indirectly the market takes part in its formation [30 - 12].

\section{GOODWILL AND METHODS OF EVALUATION}

Western companies have long estimated goodwill enterprises (goodwill), the concept of "goodwill" first appeared because of trade and finance and actively used in the Middle Ages in various 
trade unions. Currently, the most approximate to this aspect of the standards for the evaluation of goodwill standards are the ISO technical committee TC 289 "Assessment of the brand", as well as ISO standard 10668: 2010. Brand valuation - requirements for monetary brand valuation («Brand valuation - Requirements for financial valuation of the brand") [10 - 13].

The term "goodwill" in Russia until recently was used exclusively as accounting and banking terms. For each organization in the Russian Federation has the goodwill attached article. 150 of the Civil Code Russia "intangible benefits", and the object of evaluation can only serve as goodwill, set on the balance sheet. In the balance of this magnitude occurs when the company was purchased another enterprise and the cost of their own goodwill in the balance sheet is not reflected [14].

In regulatory documents, scientific and methodical literature, there is no one-valued interpretation of the concept of "goodwill" [03 - 15]. According to the Russian Accounting Regulations "Intangible Assets Accounting" (PBU 14/2007) [15]), the goodwill recorded in intangible assets, as well as works of art inventions and trademarks, and is defined as the difference between the purchase price of the company (value of property complex as a whole) and the carrying value of all its assets and liabilities. Goodwill organizations should be considered as a premium paid by the buyer in anticipation of future economic benefits, and to take into account as a separate inventory item of intangible assets. Negative goodwill in full refers to the company's financial results as other income in the full amount [15]. The rules laid down in [15], the accounting for negative goodwill close to the International Financial Reporting Standards (IFRS) [14, 16, 17].

Therefore, goodwill is a set of assets that encourage customers to use the products and services of the given company. Negative goodwill (asset value) may be the lack of stable customers, poor product quality, lack of marketing skills, low-skilled personnel, lawsuits, precedent to the manufacture of counterfeit products. Obviously, the importance of correct assessment of the reputation is especially great in the provision of services, where the cost of goodwill is significant value along with an assessment of tangible assets in determining the value of a business.

There are two approaches for the assessment of reputation: quantitative and qualitative. In practice most widely methods are method of excess profits; assessment of goodwill, based on the volume of sales index; qualimetric method and others. The qualitative approach include a method of sociological surveys and expert method, the followers of which are of the opinion that to calculate the exact amount of goodwill can't be, and can only fix it change - for the worse or better. Currently existing methods for determining the value of goodwill of the company are not universal.

The function according to the value of goodwill on the level of innovation of the company can be represented by the formula

$\mathrm{Cr}=\mathrm{f}(\mathrm{Ki}, \mathrm{D}, \mathrm{IR}$, mass media, $\mathrm{M}, \mathrm{Esin})$

where $\mathrm{Cr}$ - amount of goodwill (goodwill); $\mathrm{Ki}$ - factors indicating the effect on $\mathrm{Cr}$ enterprise products (price of products, quality, production time and other work.); D - market share of the enterprise; IR - innovative development of the enterprise; Media - the influence of the mass media (coverage of the enterprise); $M$ - marketing policy of the enterprise (promotional activities, the creation of a web site and its support and so on.); Esin - a synergistic effect on innovation and marketing development [18].

In conjunction with marketing activities and taking into account the influence of media goodwill could increase significantly under the influence necessarily resulting synergies. In the present situation the companies are given the opportunity to establish itself as the innovative development of enterprises and improve business reputation [10 - 13].

Changing the goodwill, maintaining it at a certain level, and improve the software associated with the concept of reputational risk.

Reputation risk - a set of risks resulting from the company and related to improper use of the brand, poor production of goods and services, the failure of the relevant laws, as well as the damage caused to its reputation, which threatens us in the future to lose the trust of customers, employees, shareholders, partners and other stakeholders.

Reputation should be viewed as a source of risk both in itself and as a result of interaction with other types of risks. Therefore, reputational risk is a comprehensive risk [14, 16]. Obviously, there is reputational risk for businesses of all types, 
so it is important to be able to identify, describe, analyze, assess its quality, and to make recommendations for managing them. Market assessment of reputation and associated risk now in Russia is not developed. This is due to the lack of clear formal valuation models and lack of reliable information about companies [7, 10, 12, 13, $16,17]$, as well as the absence of rules and regulations and the definition of counterfeit means of combating it [14].

So, according to [1], the Government of the Russian Federation the right to establish parties to purchases additional requirements, including the availability of business reputation. For the construction industry in Russia, the state order is the foundation of financial stability. The share purchases in the public procurement market amounts to $60 \%$ of all the ongoing tender procedures, while the market itself is far from equilibrium. The majority of construction companies - are companies that operate on the market for over 5 years, and their work is reduced to search of lucrative contracts and their implementation with the maximum benefit for themselves without regard to future orders, developed and approved by an adequate system of assessment of the experience and reputation is designed to reduce risks to market procurement of unscrupulous contractors.

\section{EVALUATIVE FACTORS OF INTANGIBLE ASSETS}

In 2014, the national standard Rosstandart approved a new Russian standard 56002-2014 "Evaluation of experience and reputation building organizations", which is designed Profit Partnership "The National Center for" the dedicated ", JSC" Institute of goodwill “, JSC" All-Russian Research Institute certification ", made by the Technical Committee for Standardization TC 066" Assessment of experience and business reputation "and establishes general requirements and criteria for evaluating models goodwill construction companies on the basis of their work experience. The standard contains the procedure for expert evaluation, evaluation model of business reputation and a number of applications, including the method of estimating the goodwill of a construction company [19].

The standard will evaluate the intangible assets on the basis of this technique, which operates five factors, each of which includes a number of subfactors with the established weight and a specific range of the evaluation (Figure 1):

- Factor "History" includes subfactors "number of years in the market" and "the rhythm of implementation";

- Factor "Means" includes subfactors "material base", "financial autonomy", "construction in progress";

- Factor "Personnel" includes subfactors "managerial skills", "middle tier", "awards and titles";

- Factor "Prestige" includes subfactors "citation", "elimination of violations", "delayed delivery of objects", "Emergencies", "certified management system", "customer feedback";

- Factor "Credibility" is a multiplier of all the factors in the model and has a default value of 1.

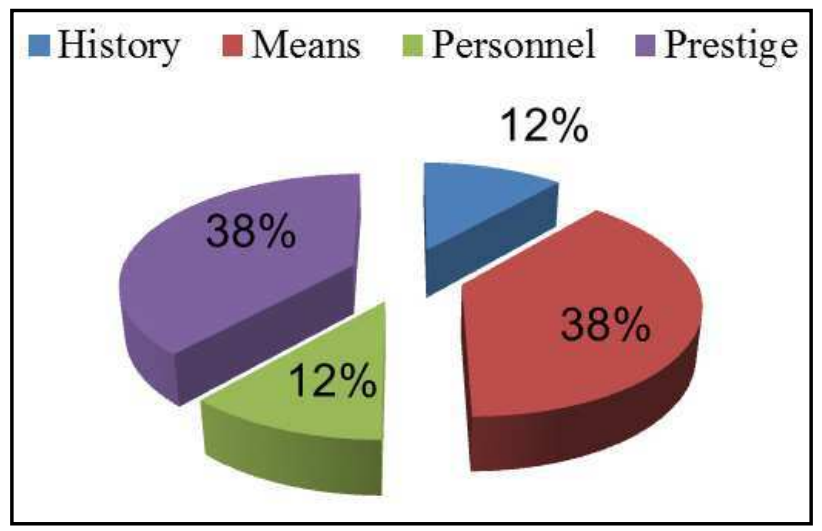

Figure 1: Evaluative factors of intangible assets of companies

The evaluation according to Russian standard 56002-2014 construction company is assigned an index of goodwill in the range from 0 to 1 . When the index is less than 0.5 the certificate of conformity is not issued a construction company, as evidenced by the extremely low level of business reputation. The highest index range -0.8 - 1.0 get market leaders [20].

In order to be an independent evaluation process, it adopted a proposal to establish a reputation in the Commission for Standardization Technical Committee 066 "Evaluation of experience and business reputation enterprises" (hereinafter - the Commission). A commission with the participation of concerned government bodies and professional associations, but the main principle of selection of representatives should be impeccable professional reputation and author- 
ity of specific expertise in the relevant field of activity. The Commission was established to improve the competitiveness of Russian business through the development of reputation-oriented approach to business, and ensure the credibility of estimates conducted by the standards developed by Technical Committee 066 .

The main task of the commission will be ensure the credibility of the standards being developed to assess the experience and reputation in different industries, and the performance of the functions of impartiality, facilitate the development of a system to assess the experience and reputation of organizations of various sectors and the credibility of the assessment [23-28].

In 2015, we developed the following new standards: Russian standard 66.0.01-2015 "Evaluation of the experience and reputation of businesses. The national system of standards. General provisions, requirements and guidelines ";

Russian standard 66.1.01-2015 "Evaluation of the experience and reputation of businesses. The national system of standards. Evaluation of the experience and reputation of persons carrying out architectural and construction design ";

Russian standard 66.1.02-2015 "Evaluation of the experience and reputation of businesses. The national system of standards. Evaluation of the experience and reputation of persons carrying out engineering surveys".

Therefore, the rating indicator provides an opportunity to get enough objective information about the terms of the company's reputation and helps to determine the strengths of the company and potential growth points. Finally, the public indicator of success is not only financial, but also the professional development of the company allows you to compare the level of development of the company and its competitors, as well as to adequately position itself in the market. An important factor is the universal assessment of the reliability of data provided by a participant ranking $[3,10-12,21,22]$.

\section{CONCLUSION}

The federal legislation includes such requirements as having the experience and reputation, but no system of recommendations that would allow the customer to navigate among the offerings on the market of goods and services. Evaluation of the experience and reputation can be carried out rating, because it achieved sufficient accuracy at a relatively low cost. The objectivity of the study will be based on expert opinion reputational Commission organized on a voluntary basis and made up of the most representative of industry experts.

For the construction industry, it is means that there will be easier access to the construction works of skilled contractors able to meet its obligations and to provide the necessary indicators of quality, reliability and security. At the same time the system will transition to a complex procurement model, which is based will lie quality and safety.

\section{REFERENCES}

1) Law № 44-FZ "About contractual system in the procurement of goods, works and services for state and municipal needs", Collection of Laws of the Russian Federation.

2) Law № 315-FZ “The self-regulatory organizations" Collection of Laws of the Russian Federation.

3) Titova, V.A., Tomilina, Y.V., Titova, T.V. (2014): "Information technology in the system of purchasing decision-making based on models of long-term and short-term marketing actions", 9th International Forum on Strategic Technology, IFOST 2014, art. no. 6991111, pp. 234-237.

4) Dunning, D., Anderson, J.E., Schlösser, T., Ehlebracht, D., Fetchenhauer, D (2014): "Trust at zero acquaintance: More a matter of respect than expectation of reward", Journal of Personality and Social Psychology, 107 (1), pp. 122-141.

5) Kuzheleva-Sagan, I.P., Suchkova, N.A. (2015): "Designing trust in the Internet services" Al and Society, p. 12.

6) Abitov, I.R. (2015): "The distinctive features of a picture of the world of the students of pharmaceutical faculty", Review of European Studies, 7 (5), pp. 47-51.

7) KyuJin Shima, Sung-Un Yangb (2015): "The effect of bad reputation: The occurrence of crisis, corporate social responsibility, and perceptions of hypocrisy and attitudes toward a company", Public Relations Review, In Press.

8) Slabá, M., Štarchoň, P., Jáč I (2014): “Identification and prioritization of key Stakeholder groups in marketing communication of colleges", E a M: Ekonomie a Management, 17 (4), pp. 101-110.

9) Höglund K., Wennerström M. (2015): "When the Going Gets Tough... Monitoring Missions 
and a Changing Conflict Environment in Sri Lanka 2002-2008", Small Wars and Insurgencies, 26 (5), pp. 836-860.

10) Mindrut, S., Manolica, A., Roman, C.T. (2015): "Building Brands Identity", Procedia Economics and Finance, Vol. 20, pp. 393-403.

11) Gurianov, P.: "Dividend policy and major shareholding profitability", Metallurgical and Mining Industry, 7 (7), 2015, pp. 101-106.

12) Gardini, S., Grossi, G. (2014): "Voluntary adoption of the consolidated financial statement and fair value accounting by Italian local governments", Journal of Public Budgeting, Accounting and Financial Management, 26 (2), pp. 313-344.

13) Schiemann, F., Richter, K., Günther, T.: "The relationship between recognised intangible assets and voluntary intellectual capital disclosure", Journal of Applied Accounting Research, 16 (2), 2015, pp. 240-264.

14) Gravit, M.V., Krivoshonok, V.V. (2015): "Standardization as an instrument for combating counterfeiting, and improve business reputation of organizations engaged in entrepreneurial activity in the field of fire safety", Fire safety, № 4, pp. 47 - 52.

15) "Approval of Accounting Regulations "Intangible Assets Accounting" "(PBU 14/2007) an order from the Russian Ministry of Finance on December 27, 2007, № 153n. Registered in the Russian Ministry of Justice on January 23. 2008 № 10975, Rossiyskaya Gazeta, N 22, 02.02.2008.

16) Zobkova, J.O., Pakhomov, A.V., Pakhomov, E.A. (2008): "An integrated approach to assessing the business reputation of the enterprise", Mathematics. Computer. Education, Coll. works of the XV International Conference. Edited by GU Riznichenko Izhevsk: Research and Publishing Center "Regular and chaotic dynamics", Vol. 1, pp. 150-153.

17) [Makarov, E.I., Dyakonova, S.N. (2012): "The dependence of the business reputation of the enterprise innovation development level", Creative Economy, № 7 (67), pp. 119-124.

18) Shlafman, A.I. (2009): "Theoretical Foundations of business regulation", Russian Entrepreneurship, vol. 1 (126), pp. 25-29.

19) Shakhov, V.: "Standard Confidence", The world of security, № 1, 2015, pp. 62 -63.

20) Suprunchuk, D.S. (2015): “The performer's reputation. On providing a standardized approach to the evaluation of experience and reputation party procurement as one of the criteria for nonad valorem", billyuteney TC 001 . For the measurement of goodwill, № 1, pp. 38 - 44 .

21) Zadorozhko, D.S. (2013): "Modern approaches to the evaluation of goodwill and reputation risk", Management of economic systems: an electronic scientific journal, № 8(56), p.34.

22) Urbanaviciene, V., Kaklauskas, A., Zavadskas, E.K., Sliogeriene, J., Naimaviciene, J., Vatin N.I. (2014): "Facilitating the housing bargaining with the help of the bargaining decision support system", International Journal of Strategic Property Management, 18 (3), pp. 213-224.

23) Ćetković, J., Knežević, M., Žarković, M., Murgul, V., Vatin, N. Development and competitiveness improvement of the construction sector in Montenegro (2014) Applied Mechanics and Materials, Vols. 638-640, pp. 2465-2470.

24) Ćetković J., Rutešić S., Zarković M., Knežević M., Vatin N. (2015): Primary directions and advancements in competitiveness of montenegrin construction sector, Procedia Engineering, 117 (1), pp. 780-790.

25) Rutešić S., Ćetković J., Žarcković M., Knežević M., Vatin N. (2015): Analysis of the situation in montenegrin civil engineering sector from the point of application of national regulations and the EU technical standards in construction, Procedia Engineering, 117 (1), pp. 905-915.

26) Rutešić S., Ćetković J., Knežević M., Žarcković M., Vatin N. (2015): Institutional framework, current investments and future strategic direction for development of construction sector in Montenegro, Procedia Engineering, 117 (1), pp. 642-650.

27) Jevrić M., Knežević M., Kalezić J., Kopitović Vuković N., Ćipranić I. (2014): Application of fractal geometry in urban pattern design [Primjena fraktalne geometrije u projektiranju gradskog obrasca] Tehnicki Vjesnik, 21 (4), pp. 873-879.

28) Lazarevska M., Knezevic M., Cvetkovska M., Trombeva Gavriloska A. (2014): Application of artificial neural networks in civil engineering [Primjena umjetnih neuronskih mreža u građevinarstvu] Tehnicki Vjesnik, 21 (6), pp. 1353-1359.

Paper sent to revision: 29.01.2016.

Paper ready for publication: 14.03.2016. 
doi:10.5937/jaes14-10455

Broj rada: 14(2016)1, 364

\section{UTICAJ POSLOVNE REPUTACIJE NA REZULTATE DELATNOSTI ORGANIZACIJE GRAEEVINSKE SFERE}

Vladimir Okrepilov, Državni Regionalni Centar za Standardizaciju, Metrologiju i Testiranje, St. Petersburg, Rusija

Marina Gravit, Državni Regionalni Centar za Standardizaciju, Metrologiju i Testiranje, St.

Petersburg, Rusija

Ekaterina Nedviga, Državni Regionalni Centar za Standardizaciju, Metrologiju i Testiranje,

St. Petersburg, Rusija

Dudnik Oleg, Državni Regionalni Centar za Standardizaciju, Metrologiju i Testiranje, St. Petersburg, Rusija

Razmotrena su pitanja poslovne reputacije organizacije i reputacionog rizika. Posebna pažnja posvećena je razradi nacionalnih standarda po oceni iskustva i poslovnoj reputaciji organizacije. Dati opis i osnova stvaranja standarda po oceni iskustva i poslovnoj reputaciji građevinskih organizacija. Rasmotrena je metodika ocenjivanja poslovne reputacije, dozvoljavajući ocenjivanje nematerijalnih aktiva građevinskog preduzeća. Metodika uključuje u sebe pet faktora, od kojih svaki uključuje u sebe niz podfaktora. U rezultatu ocenjivanja u skladu sa datom metodikom po standardu GOST R 56002-2014 "Ocena iskustva i poslovne reputacije građevinskih organizacija» građevinskoj kompaniji dodeljuje se određeni indeks poslovne reputacije.

Ključne reči: Poslovna reputacija, Reputacioni standard, Metodika ocenjivanja, Građevinarstvo 